Original paper

\title{
Fingerprints of magma mingling processes within the Miocene Zebín tuff cone feeding system (Jičín Volcanic Field, Czech Republic)
}

\author{
Vladislav RAPPRICH ${ }^{1 *}$, Sarah SHIELDS ${ }^{20}$, Patricie HALODOVÁ 1 , Jennifer LINDLINE², \\ Benjamin van WYK de VRIES ${ }^{3}$, Michael S. PETRONIS ${ }^{2}$, Jan VALENTA ${ }^{4}$
}

\author{
${ }^{1}$ Czech Geological Survey, Klárov 3, 11821 Prague 1, Czech Republic; vladislav.rapprich@geology.cz \\ ${ }^{2}$ Environmental Geology Program, Natural Resources Management Department, New Mexico Highlands University, Las Vegas, \\ NM 87701, USA \\ ${ }^{3}$ Université Clermont Auvergne, CNRS, IRD, OPGC, Laboratoire Magmas et Volcans, F-63000 Clermont-Ferrand, France \\ ${ }^{4}$ Institute of Hydrogeology, Engineering Geology and Applied Geophysics, Faculty of Science,Charles University, Albertov 6, 12843 \\ Prague 2, Czech Republic \\ * Corresponding author \\ ${ }^{\circ}$ Currently at Department of Geology, University of Wisconsin, Madison, WI, USA
}

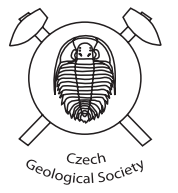

\begin{abstract}
A well-preserved set of partly eroded mid-Miocene scoria cones and tuff cones are exposed in the Jičín Volcanic Field, Czech Republic. Zebín Hill, a formerly quarried tuff cone with an exposed conduit and associated dikes, offers an opportunity to study magmatic processes within the high-level feeding system of a small monogenetic volcano. Two types of dikes and associated "blob-like" intrusions were observed. Pure basanite dikes predominate in the center of the cone, whereas its peripheries were intruded by mingled dikes. The mingled dikes consist of mm-scale basanitic domains enclosed in a network of trachyandesitic dikelets. Locally, hybrid domains with intermediate characteristics were observed. The basanite dikes and basanite enclaves within mingled dikes contain normally-zoned minerals $\left(\mathrm{Fo}_{90}\right.$ to $\mathrm{Fo}_{70}$ olivine, $\mathrm{Mg}$-rich to $\mathrm{Mg}$-poor diopside, labradorite to andesine composition of plagioclase) indicative of basanite magma evolution during ascent. In contrast, the trachyandesite and hybrid enclaves in mingled dikes show reverse zoning of minerals (Mg-poor to Mg-rich diopside, sanidine to oligoclase feldspar composition) indicative of magma hybridization.

This study suggests that the Zebín Volcano did not develop from a simple monogenetic system and through a single central axis feeder; rather, Zebín Hill evolved from a complex magma feeding/storage system and through a complex feeder network. We conclude that the simple external structure of a monogenetic volcano may sometimes hide rather complex magmatic plumbing systems encompassing compositionally contrasting rocks/magmas.
\end{abstract}

Keywords: magma mingling, basanite, trachyandesite, mineral chemistry, Zebín tuff cone, Jičin Volcanic Field

Received: 10 July, 2017; accepted: 7 December, 2017; handling editor: J. M. Hora

The online version of this article (doi: 10.3190/jgeosci.245) contains supplementary electronic material.

\section{Introduction}

Monogenetic volcanoes are generally described as relatively simple and small volcanic systems with predictable magma evolution, emplacement dynamics and hazards (e.g., Németh 2010; Pérez-López et al. 2011). Recent studies show, however, that even small basaltic volcanoes may display a complex sub-volcanic structure (e.g., Petronis et al. 2013, 2015; Blaikie et al. 2014; Shields et al. 2016), long-lived magmatic emplacement, and unpredictable eruption scenarios including the production of mafic pyroclastic flows (Rosi et al. 2006; Di Roberto et al. 2014). From petrological point of view, individual monogenetic volcanoes are usually characterized by simple composition, although compositionally-simple monogenetic volcanoes may be clustered in volcanic fields of wider compositional spectra (e.g., Delacour et al. 2007; Orozco-Esquivel et al. 2007; Hamelin et al. 2009; Büchner et al. 2015; Awdankiewicz et al. 2016; Ulrych et al. 2016). More diversified compositional settings are rather restricted to composite volcanic edifices, or to the eruptions from zoned chambers (e.g., Klügel et al. 2000).

Though rare, complex magmatic systems feeding monogenetic volcanoes (Schreiber et al. 1999; Németh et al. 2003; Brenna et al. 2010; Erlund et al. 2010; Jankovics et al. 2015) document that multifaceted magma feeding/storage systems may develop even at small scales. Here we present textural and mineral chemistry evidence of complex basanite-trachyandesite magma evolution within a feeding system of an intra-continental monogenetic Zebín tuff cone in the Jičín Volcanic Field (Czech Republic). 


\section{Geological setting}

\subsection{Jičín Volcanic Field}

The Bohemian Massif in Central Europe experienced extensive episodic magmatic/volcanic activity during the Cenozoic (e.g., Ulrych et al. 2011 and references therein). The intra-plate alkaline magmas were derived from upper mantle due to extension-controlled adiabatic decompression. Most of the magmatism was concentrated along the Eger Rift, which represents the easternmost branch of the European Cenozoic Rift System (e.g., Dèzes et al. 2004; Rajchl et al. 2008). Apart from the main volcanic complexes (see e.g., Ulrych et al. 2002; Rapprich and Holub 2008; Cajz et al. 2009; Holub et al. 2010; Skála et al. 2014; Ackerman et al. 2015), several volcanic fields were formed also on the shoulders of the rift (Awdankiewicz 2005; Rapprich et al. 2007; Büchner and Tietz 2012; Valenta et al. 2014; Büchner et al. 2015; Petronis et al. 2015; Tietz and Büchner 2015; Awdankiewicz et al. 2016; Ulrych et al. 2016; Haase et al. 2017). Our study focused on the Zebín Volcano, located in the Jičín Volcanic Field (Rapprich et al., 2007; Petronis et al. 2015; Fig. 1) on the southeastern shoulder of the Eger Rift, where Miocene volcanic rocks were emplaced into, or erupted onto, Upper Cretaceous marine sediments of the Bohemian Cretaceous Basin and continental Permo-Carboniferous strata of the Krkonoše Piedmont Basin. This area experienced only a moderate degree of erosion since the Miocene exposing the magma feeding systems together with preserved superficial facies of volcanic edifices.

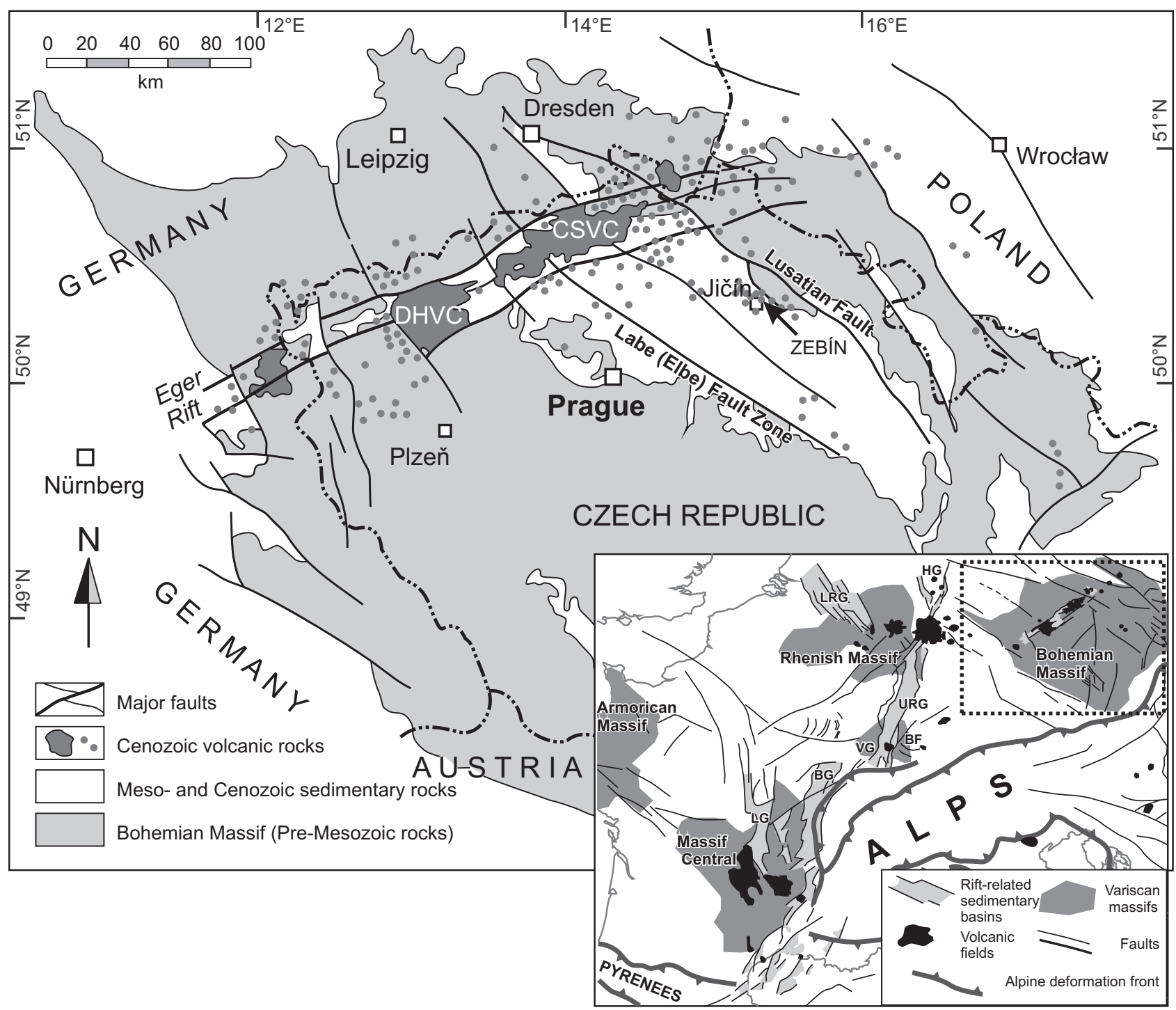

Fig. 1 Location of the Zebín tuff cone in the Bohemian Massif, the inset figure shows position of the Bohemian Massif within European Variscides and the European Cenozoic Rift System. BF - Black Forest, BG - Bresse Graben, CSVC - České Středohoří Volcanic Complex, DHVC - Doupovské hory Volcanic Complex, HG - Hessian Grabens, LG - Limagne Graben, LRG - Lower Rhine Graben, URG - Upper Rhine Graben, VG - Vosges. 


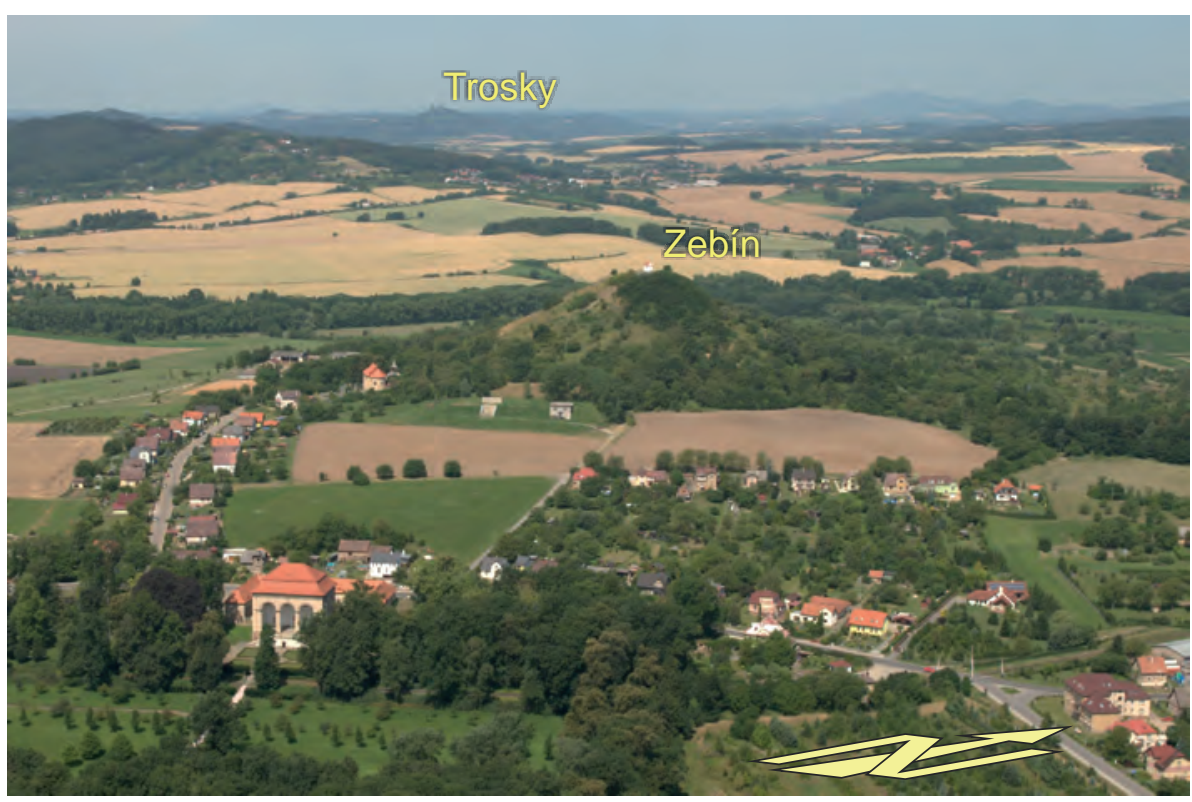

Fig. 2 View of Zebín Hill from southeast. Nearby Trosky Volcano (Petronis et al. 2015) is also indicated. Photo by A. Tauchman.

center of Jičín Town. The volcanic activity of Zebín was

The tectonic framework in the wider area of the Jičín Volcanic Field located south of the NE-SW trending Eger Rift was influenced by the structure of the Bohemian Cretaceous Basin. The basin formed in a dextral transpressional to transtensional fault system of NW-SE orientation (nearly perpendicular to the trend of Eger Rift; Fig. 1) with two dominant fault systems; Labe Fault Zone and Lusatian Fault Zone (e.g., Uličný 2001; Uličný et al. 2009; Coubal et al. 2014). The NW-SE trending system of faults controlled the formation of the basin and remained prominent until Quaternary. NNWSSE trending synthetic and $\mathrm{N}-\mathrm{S}$ trending antithetic Riedel-shears are associated with these fault zones. The distribution of the Cenozoic volcanoes follows the above-mentioned dominant fault systems as they controlled the magma ascent (Vaněčková et al. 1993). The E-W trending tectonic grain, however, was the leading factor that influenced the geometry of the dikes and magma feeder conduits at shallow crustal depths (Rapprich et al. 2007; Petronis et al. 2015). Volcanic activity in the Jičín Volcanic Field occurred during two separate episodes: (1) Early Miocene (19-16 Ma) and (2) Early Pliocene (5-4 Ma). Eruptions occurred from scattered vents in the form of lava flows, lava lakes, phreatomagmatic craters, and scoria cones and tuff cones. Compositionally the rocks are intra-plate alkaline basalts sensu lato, including picrobasalt, basanite, and olivine nephelinite (Rapprich et al. 2007).

\subsection{Zebín Volcano}

Zebín Hill (399 m a.s.l.) is a picturesque cone-shaped knob rising $100 \mathrm{~m}$ above the surrounding landscape (Fig. 2), about $2 \mathrm{~km}$ to the northeast from the historical dated by the $\mathrm{K}-\mathrm{Ar}$ bulk rock method at $17.51 \pm 0.74 \mathrm{Ma}$ (Rapprich et al. 2007). The volcano was constructed upon marine marlstones and claystones of Late Turonian to Early Coniacian age (e.g., Čech 2013). The internal plumbing system and cone facies of Zebín Hill are well exposed in an abandoned quarry on the western slope of the volcanic remnant (Fig. 3). The quarry was operating mainly in the period between the $17^{\text {th }}$ and the $19^{\text {th }}$ centuries and focused on mining the coherent feeder dikes used for building stones and crushed for road gravels.

At Zebín Hill, the coherent dikes intruded into lapillistone (Fig. 3). The pyroclastic deposits are well-sorted and clast supported with indistinctive outward dipping bedding suggesting the Zebín Hill represents a remnant of pyroclastic cone with preserved wall facies (Rapprich et al. 2007). The pyroclastic deposits consist of angular non-vesiculated fragments of basanite with predominating size around $1 \mathrm{~cm}$ and with numerous xenoliths of underlying Cretaceous sediments (Fig. 4a). The fine-grained character of the deposits and poor vesicularity of the magmatic fragments suggest quench fragmentation with inhibited vesiculation during a phreatomagmatic eruption. Apparently, in the course of the eruption, the explosive site did not propagate downwards to create a maar crater (sensu Lorenz and Kurszlaukis 2007); rather, it produced in a tuff cone. This assumption is also supported by the scarcity of lithics. A different eruptive scenario is interpreted at Trosky Volcano (Petronis et al. 2015; Figs 2 and 4) in a contrasting paleo-environmental setting. While Trosky Volcano erupted upon well-drained and dry sandstones, the eruptions of Zebín took place in wetlands on impermeable marlstones and claystones (Fig. 4b). At the latter locality, slight variation was observed in the pyroclastic deposits from the base upwards. The lower part is 


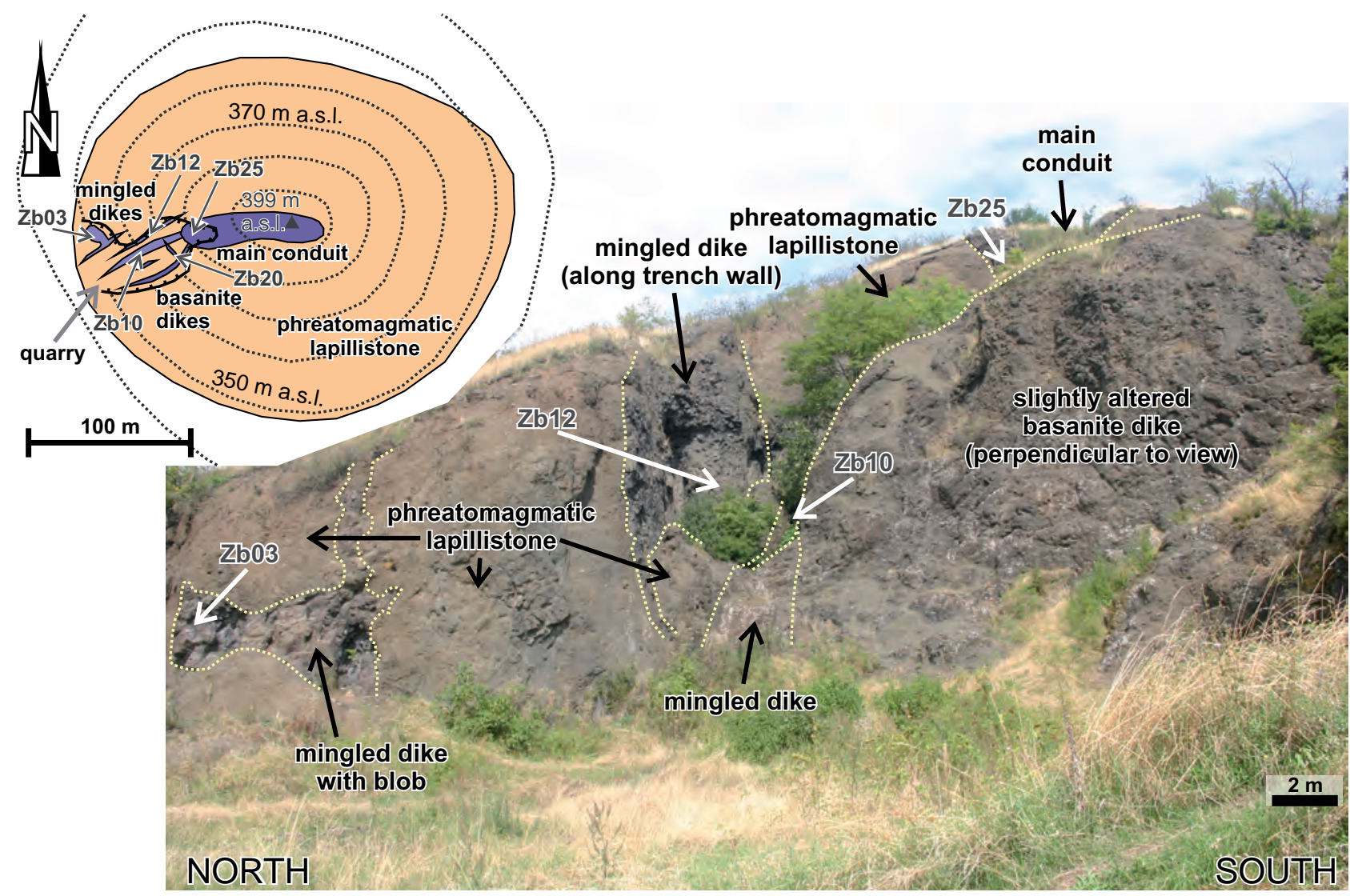

Fig. 3 View of the abandoned quarry on Zebín Hill with sample locations indicated, shown also on the schematic map (left top corner).

massive in structure and enriched in xenoliths and probably corresponds to a coarse-grained basal phreatomagmatic layer (sensu Schmincke 1977). Marlstone xenoliths content decreases upwards (from $\sim 40 \%$ to less than $10 \%$ ) as does the content of larger $(>5 \mathrm{~cm})$ basanite fragments. In this study, we focused on coherent intrusive rocks that penetrate the pyroclastic deposits.

\section{Methods}

\subsection{Field work}

Field studies included detailed geologic mapping of the Zebín Hill quarry walls and surrounding exposures, as well as sampling of the volcanic rocks. With an aim to continue with AMS and paleomagnetic studies, the samples were collected as oriented

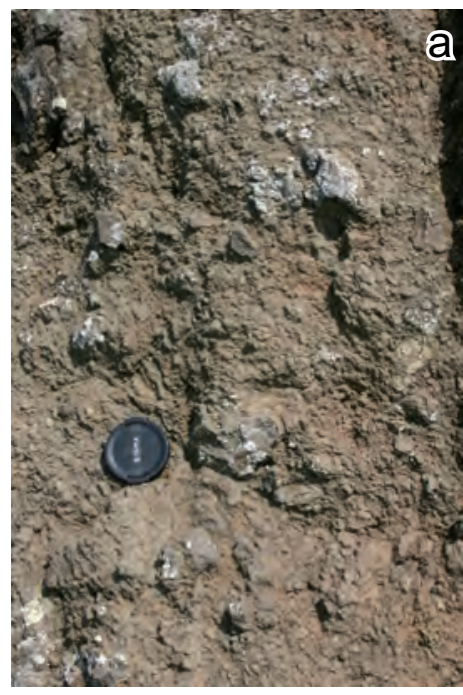

well-drained sandstones of Hrubá Skála

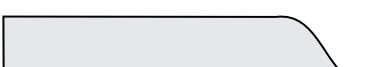

swampy landscape upon claystones in the Jičín surroundings

\section{Strombolian-style}

eruption in dry environment

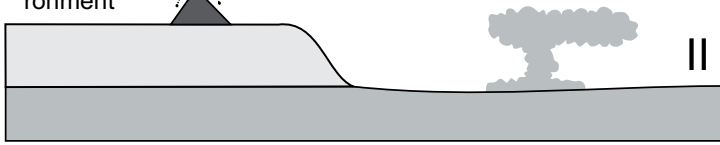

Trosky scoria-

cone
Zebín tuff-cone drill-cores using a portable gasoline-powered $\mathrm{ECHO} 280 \mathrm{E}$ drill with a nonmagnetic diamond-tipped bit. All samples were oriented using a magnetic and, when possible, a sun compass. The samples were thin-sectioned by High Mesa Petrographics, Los Alamos, NM, for further petrological research.

Fig. 4a - Lapillistone on Zebín Hill; III $\mathbf{b}$-Schematic comparison of eruptive history for Trosky and Zebín volcanoes. 


\subsection{Petrography and mineral chemistry}

The thin sections were studied under a standard petrographic microscope. The microscopic observations were supported by mineral chemistry. Quantitative chemical analyses of individual minerals were conducted on a Tescan MIRA 3GMU scanning electron microscope (SEM) at Czech Geological Survey, Prague-Barrandov fitted with SDD X-Max $80 \mathrm{~mm}^{2}$ EDS detector and AZtecEnergy software (Oxford Instruments).

Point analyses of selected minerals and area analyses on parts of the sample were acquired under the following conditions: accelerating voltage $15 \mathrm{kV}$, working distance $15 \mathrm{~mm}, 3 \mathrm{nA}$ probe current, $30 \mathrm{~s}$ acquisition time, focused electron beam diameter $30 \mathrm{~nm}$. Mineral standards (SPI) were used for standardization, pure Co for quant optimization. The method of Vieten and Hamm (1978), which balances the deficiency of oxygen atoms corresponding to 4 cations (with all iron as $\mathrm{Fe}^{2+}$ ), was used to calculate $\mathrm{Fe}^{3+}$ contents in clinopyroxenes. The same method based on 3 cations was applied to $\mathrm{Fe}-\mathrm{Ti}$ oxides.

The areal (bulk-rock) analyses have reduced totals (95.1-99.3 wt. \%), because all iron is presented as $\mathrm{FeO}$, the analyses do not include volatiles, and small irregularities on the surface may reduce the amount of diffracted X-rays. Glasses in the basanite dike Zb20 are partly hydrated resulting in reduced totals, but proportions among individual oxides appear stable (except for calcium which is discussed), suggesting the recalculation to water-free basis can be applied to these measurements.

\subsection{Whole-rock chemistry}

Several dikes contain domains of distinct petrography. As the individual domains were too small for mechanical separation and application of routine bulk-rock analytical methods, their compositions were determined by integral analysis of defined quadrangles using the SEM. These zones yielded compositional data representative of the discrete magma batches.

The chemical analyses of microscopic-scale domains obtained by SEM were compared to standard whole-rock chemical analysis of the coherent rock from the main plug (sample CR009). The major-element contents in this sample were determined by conventional wet analysis, following the methodology described in Dempírová et al. (2010). This method involves initial dissolution using $\mathrm{HF}+\mathrm{HNO}_{3}+\mathrm{H}_{2} \mathrm{SO}_{4}$ at $220^{\circ} \mathrm{C}$ for determination of $\mathrm{SiO}_{2}$, followed by a digestion in a $\mathrm{HCl}+\mathrm{H}_{2} \mathrm{SO}_{4}$ mixture for determination of the remaining oxides. The analytical data were visualized using GCDkit software (Janoušek et al. 2006).

\section{Results}

\subsection{Petrography and major-element chemistry}

The pyroclastic deposits of the Zebín Volcano were intruded by bodies of coherent magma. The central part of the hill is built by a main conduit plug associated with numerous thinner dikes. The main plug and dikes close to the main plug consist of coherent pure basanite, whereas the peripheral dikes are of mingled character and comprise a mixture of domains, enclaves, and veinlets of variable composition. Some of the peripheral mingled dikes (10-200 cm across) are associated with "blob"-like intrusions $(3 \times 4 \mathrm{~m})$ emplaced into pyroclastic deposits (Fig. 3). Unlike the dikes, the pyroclastic deposits are compositionally homogeneous (except for mantle and crustal xenoliths), without any signs of presence of distinct magma batches.

The petrographic character of the pure basanites was studied on samples Zb25 (main plug) and Zb20 (dike close to the main plug). The basanite is fine-grained, porphyritic, and dominated by optically conspicuous olivine phenocrysts $1-4 \mathrm{~mm}$ across representing around 8 vol. \% of the rock. The olivine is altered along rims and fractures, but contains also fresh cores of the crystal fragments (Fig. 5a). Larger olivine grains (up to $7 \mathrm{~mm}$ ) are fragmental with oval shapes; these appear to represent partly resorbed mantle-derived xenocrysts. Clinopyroxene phenocrysts are less frequent and smaller in size (mostly around $1 \mathrm{~mm}$, scarcely $2 \mathrm{~mm}$ ). Most of the phenocryst cores are colorless with pale pink-brownish rims, suggesting increased admixture of Ti and $\mathrm{Al}$. Cores of some clinopyroxene phenocrysts display sieve texture and differ in brownish to greenish color. The groundmass is dominated by small acicular euhedral crystals of clinopyroxene, fresh olivine, magnetite and plagioclase intergrown with anhedral nepheline (Fig. 5a). The intergrowth of plagioclase and nepheline is typical of the main plug, whereas brownish isotropic glass occurs in the dike, where more rapid cooling took place. Magnetite is cubic and blocky, present as variably sized grains $(5-50 \mu \mathrm{m})$ throughout the rock. Small opaque grains (magnetite or chromite) are also present as inclusions in the larger clinopyroxene and olivine phenocrysts. Mantle xenoliths (peridotites, not exceeding $5 \mathrm{~cm}$ ) consisting of olivine, orthopyroxene, clinopyroxene and opaque phases are commonly found in the thin sections as well as macroscopically on the hand-specimens and outcrops. Scarce quartz xenocrysts have reaction rims or are completely replaced by a mixture of glass and clinopyroxene.

The mingled character typical of some peripheral dikes was represented by samples $\mathrm{Zb03}, \mathrm{Zb10}$, and $\mathrm{Zb} 12$. The complex magma mingling textures were not well visible in hand-sample, but were obvious in thin section. These 

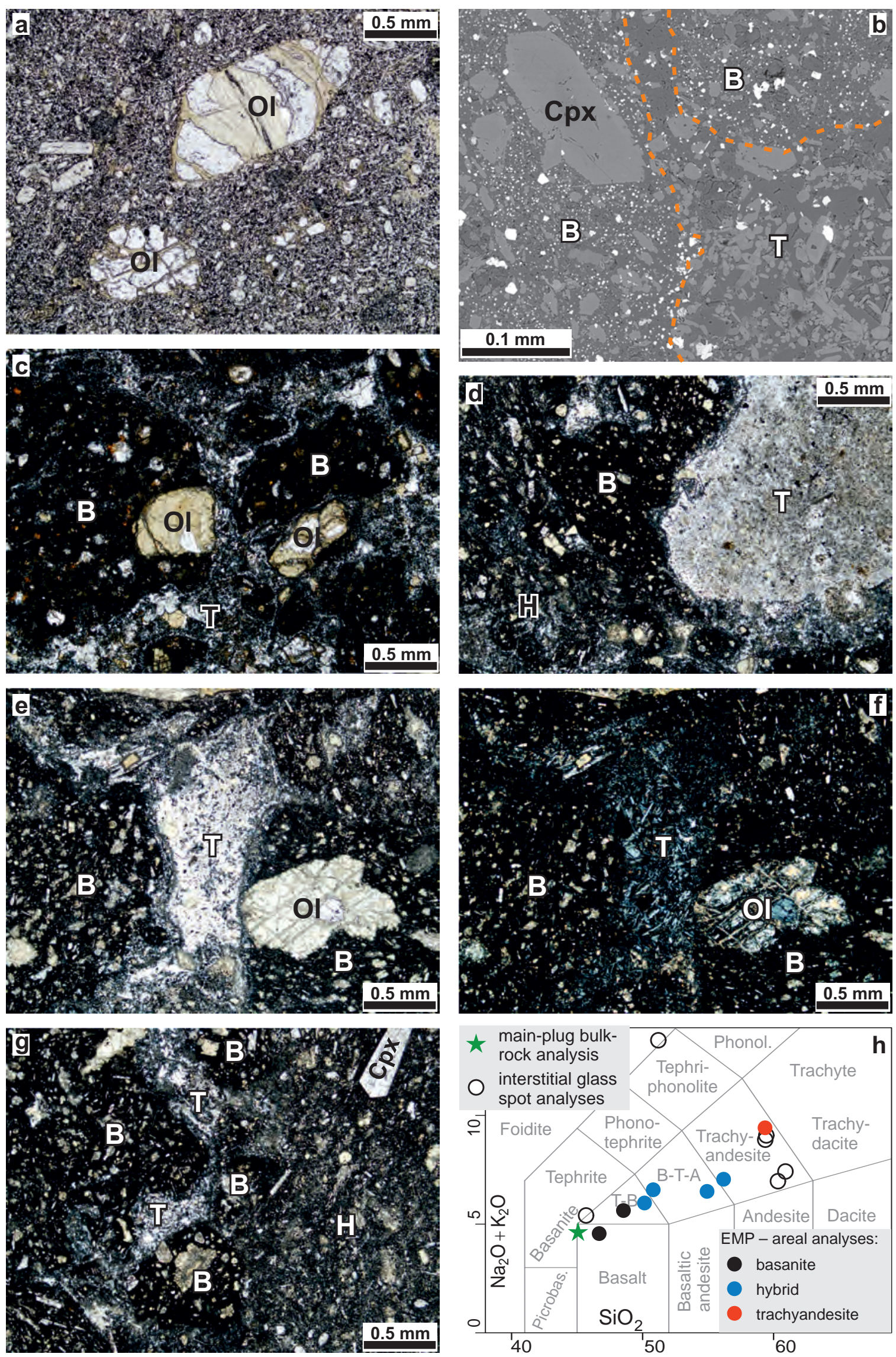
Tab. 1 Major-element data (in wt. \%) of the whole-rock sample CR009 from the main conduit, and microprobe areal analyses of individual magma batches in mingled dikes

\begin{tabular}{|c|c|c|c|c|c|c|c|c|}
\hline Sample & CR009 & 265 & 300 & 264 & 357 & 299 & 371 & 263 \\
\hline Unit & Main conduit & \multicolumn{7}{|c|}{ Mingled dikes } \\
\hline Rock sample & & $\mathrm{Zb} 12$ & Zb12 & $\mathrm{Zb} 12$ & Zb10 & Zb12 & Zb10 & $\mathrm{Zb} 12$ \\
\hline Domain & & basanite clast & basanite clast & hybrid clast & hybrid clast & hybrid veinlet & hybrid veinlet & $\begin{array}{c}\text { trachyandesite } \\
\text { veinlet }\end{array}$ \\
\hline Area measured $\left(\mu \mathrm{m}^{2}\right)$ & & 265 & 115 & 138 & 190 & 82 & 225 & 153 \\
\hline $\mathrm{SiO}_{2}$ & 43.13 & 44.30 & 46.77 & 54.56 & 49.81 & 52.53 & 49.04 & 58.41 \\
\hline $\mathrm{TiO}_{2}$ & 2.72 & 2.76 & 2.77 & 0.75 & 2.36 & 0.73 & 2.15 & 1.22 \\
\hline $\mathrm{Al}_{2} \mathrm{O}_{3}$ & 12.82 & 15.42 & 15.79 & 17.69 & 17.49 & 12.19 & 13.11 & 14.58 \\
\hline $\mathrm{FeOt}$ & 10.96 & 11.30 & 9.15 & 5.23 & 9.05 & 5.99 & 8.03 & 4.40 \\
\hline $\mathrm{MnO}$ & 0.22 & 0.21 & 0.15 & b.d.l. & b.d.l. & 0.19 & 0.18 & b.d.l. \\
\hline $\mathrm{MgO}$ & 10.86 & 6.49 & 5.13 & 3.62 & 5.00 & 7.17 & 7.13 & 3.71 \\
\hline $\mathrm{CaO}$ & 10.14 & 9.44 & 10.39 & 8.40 & 8.83 & 10.42 & 10.06 & 6.82 \\
\hline $\mathrm{Na}_{2} \mathrm{O}$ & 3.47 & 3.25 & 4.58 & 5.66 & 4.83 & 4.49 & 5.72 & 4.80 \\
\hline $\mathrm{K}_{2} \mathrm{O}$ & 0.95 & 1.08 & 0.84 & 1.20 & 1.10 & 1.73 & 0.63 & 4.48 \\
\hline $\mathrm{P}_{2} \mathrm{O}_{5}$ & 0.62 & 0.85 & 0.94 & b.d.1. & 0.86 & 0.40 & 0.64 & b.d.1. \\
\hline Total & 99.62 & 95.11 & 96.51 & 97.11 & 99.33 & 95.98 & 96.69 & 98.42 \\
\hline
\end{tabular}

b.d.l. - below detection limit

rocks consist of small droplets of basanite (4-8 $\mathrm{mm})$ enclosed in a network of trachyandesite veinlets (Figs 5b-c). The basanite droplets have the same porphyritic texture as the pure basanite in the main plug or proximal dike, with large but completely altered olivines in a fine-grained, dark groundmass rich in very fine opaque grains (Figs 5c, e-f). The trachyandesite is likewise present as scarce enclaves (4 mm) with fine-grained aphanitic texture (Fig. 5d) but prevails in the form of thin veinlets (under $0.2 \mathrm{~mm}$ thick) with rare thicker domains (Figs 5b, e-f).

The trachyandesite differs from the basanite in color (Figs 5c, e) as well as in texture which is equigranular and more coarse-grained (Fig. 5b). The trachyandesite domains are dominated by sanidine with subordinate clinopyroxene. Opaque minerals are represented by coarser grains, rather than the fine grains typically dispersed throughout the basanites. The composition of the opaque phases in trachyandesite domains corresponds to Ti-poor magnetite and ilmenite.

Small pleochroic biotite flakes occur in both trachyandesite and basanite domains. Magmatic olivine and the mantle-derived xenocrysts (olivine and orthopyroxene) are

Fig. 5 Rock textures and composition: a - Porphyric basanite of the main plug with $1.5 \mathrm{~mm}$ large olivine (Ol) phenocrysts (sample $\mathrm{Zb} 25$, PPL - plane polarized light) enclosed in groundmass of olivine, clinopyroxene, magnetite, plagioclase and nepheline; $\mathbf{b}$ - Droplets of basanite (B) with clinopyroxene phenocrysts ( $\mathrm{Cpx}$ ) separated by trachyandesite veinlet (T) (back-scattered electron image); $\mathbf{c}$ - Trachyandesite veinlets (T) branching between basanite droplets (B) with olivine phenocrysts (O1) (PPL); $\mathbf{d}$ - Larger trachyandesitic clast (T) and basanite droplets surrounded by hybrid rock; e-f - Trachyandesite pocket (T) between two basanite clasts (B) (e - PPL, f - cross-polarized light); g - Contact of hybrid rock $(\mathrm{H})$ with mixture of basanite droplets $(\mathrm{B})$ and trachyandesite veinlets (T) (PPL); h - Total alkali-silica (TAS) discrimination diagram (Le Maitre et al. 2002) with glass and bulk-rock data. T-B trachybasalt, B-T-A - basaltic trachyandesite. completely altered. In some of the samples, hybrid domains were observed. The hybrid domains were distinguished by a moderate grey color (Figs 5d, g) and an assemblage of plagioclase, alkali feldspar and significant clinopyroxene (even larger phenocrysts up to $1 \mathrm{~mm}$ ) with remnants of altered olivine (much smaller). Veinlets of hybrid rocks usually crosscut the mingled texture of basanite droplets enclosed in a network of trachyandesite veinlets (Fig. 5g).

The whole-rock composition of the main plug basanite (Tab. 1) falls on the boundary between basanite and basalt fields in the TAS diagram (Fig. 5h). This composition can be compared with data of individual enclaves from the mingled dikes. The basanite droplets plot in the fields of basalt and trachybasalt (higher silica probably results from selection of the domains without large olivine phenocrysts, this fact is also reflected by lower $\mathrm{MgO}$ - see Tab. 1). The trachyandesite veinlets plot in the trachyandesite field (Fig. 5h). Hybrid domains show wide range of compositions between basanite and trachyandesite end-members. General trends from basanite through hybrid rocks toward trachyandesite can be observed also from binary plots of silica versus $\mathrm{TiO}_{2}, \mathrm{FeO}, \mathrm{MgO}$, and $\mathrm{CaO}$ (Fig. 6). Except for $\mathrm{CaO}$, this trend is also followed by spot analyses of interstitial glasses. The data from spot analyses of glasses in the basanite dike Zb20 (Tab. 2) plot in the TAS diagram close to the trachyandesite veinlet (Fig. $5 \mathrm{~h})$ analysis, despite having significantly higher $\mathrm{Al}_{2} \mathrm{O}_{3}$ content (16.2-22.5 wt. \% compared to $14.6 \mathrm{wt}$ \%) and lower $\mathrm{CaO}$ content $(0.2-0.8$ wt. \% compared to 6.8 wt. \%; Fig. 6d). The loss in calcium may correspond to slight alteration evident from the low totals. The interstitial glass measured in the main conduit (sample $\mathrm{Zb} 25$ ) differs by high amounts of $\mathrm{Al}_{2} \mathrm{O}_{3}(27$ wt. \%) and $\mathrm{Na}_{2} \mathrm{O}$ (11.6 wt. \%), having strong phonolitic tendency 

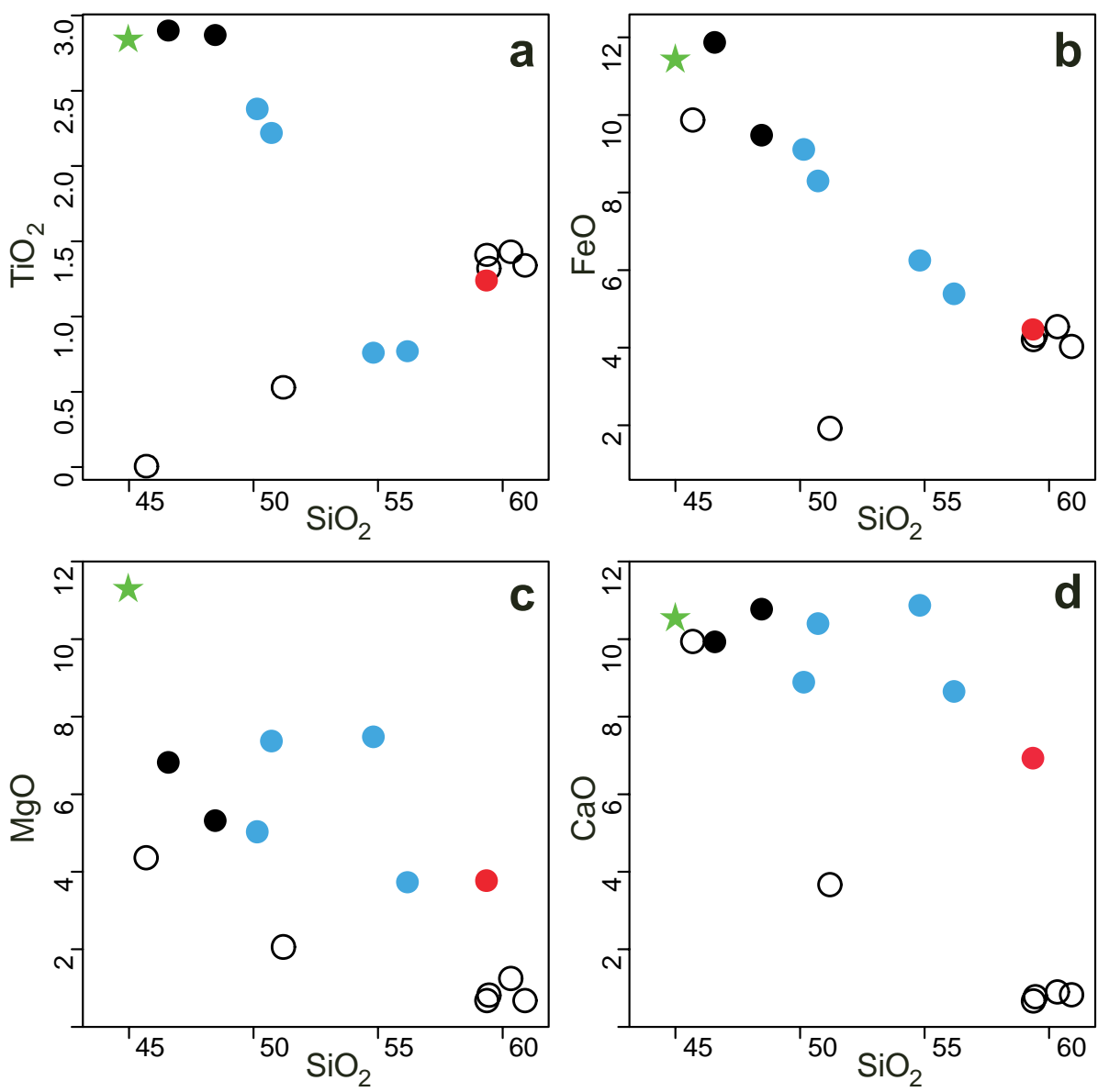

Fig. 6 Selected Harker plots (all in wt. $\%$, recalculated to volatiles-free basis). Symbols correspond to Fig. $5 \mathrm{~h}$.

(Fig. 5h). On the other hand, the glass documented in the basanite droplet within the mingled dike has composition similar to whole-rock basanitic domains, with significant differences in increased $\mathrm{P}_{2} \mathrm{O}_{5}(5.3$ wt. \%) and decreased $\mathrm{MgO}$ (4.2 wt. \%; Fig. 6c). Namely the disparity in $\mathrm{MgO}$ content can be explained in terms of presence (bulk rock) vs. absence (glass) of the olivine phenocrysts.

\subsection{Mineral chemistry}

\subsubsection{Olivine}

Olivine occurs unaltered in the basanite plug and unmingled basanite dikes, whereas olivine in the mingled rocks, even in the basanite clasts and droplets, is completely altered. Olivine is present as both, large phe-

Tab. 2 Major-element spot-analyses of interstitial glass (in wt. \%)

\begin{tabular}{|c|c|c|c|c|c|c|c|}
\hline Sample & 104 & 173 & 174 & 195 & 204 & 228 & 276 \\
\hline Unit & Main conduit & \multicolumn{5}{|c|}{ Basanite dike } & $\begin{array}{l}\text { Basanite clast } \\
\text { in mingled dike }\end{array}$ \\
\hline Rock sample & $\mathrm{Zb} 25$ & $\mathrm{Zb} 20$ & Zb20 & Zb20 & Zb20 & $\mathrm{Zb} 20$ & $\mathrm{Zb} 12$ \\
\hline Domain & glass & glass & glass & glass & glass & glass & glass \\
\hline $\mathrm{SiO}_{2}$ & 50.84 & 54.22 & 54.61 & 54.01 & 65.50 & 53.74 & 44.43 \\
\hline $\mathrm{TiO}_{2}$ & 0.53 & 1.20 & 1.30 & 1.19 & 0.71 & 1.27 & b.d.l. \\
\hline $\mathrm{Al}_{2} \mathrm{O}_{3}$ & 26.96 & 21.75 & 22.46 & 21.68 & 16.25 & 21.58 & 18.76 \\
\hline $\mathrm{FeOt}$ & 1.91 & 3.94 & 3.87 & 3.57 & 1.59 & 4.04 & 9.60 \\
\hline $\mathrm{MnO}$ & b.d.1. & b.d.1. & b.d.1. & b.d.1. & b.d.l. & b.d.l. & b.d.l. \\
\hline $\mathrm{MgO}$ & 2.05 & 0.75 & 0.63 & 0.60 & 1.19 & 1.11 & 4.24 \\
\hline $\mathrm{CaO}$ & 3.64 & 0.71 & 0.62 & 0.74 & 0.20 & 0.80 & 9.67 \\
\hline $\mathrm{Na}_{2} \mathrm{O}$ & 11.56 & 4.05 & 4.14 & 3.50 & 3.59 & 3.25 & 3.38 \\
\hline $\mathrm{K}_{2} \mathrm{O}$ & 1.80 & 4.23 & 4.03 & 3.08 & 3.32 & 2.96 & 1.87 \\
\hline $\mathrm{P}_{2} \mathrm{O}_{5}$ & b.d.l. & 0.36 & 0.33 & 0.31 & b.d.1. & 0.32 & 5.30 \\
\hline Total & 99.29 & 91.21 & 91.99 & 88.76 & 92.36 & 89.08 & 97.23 \\
\hline
\end{tabular}

b.d.1. - below detection limit 

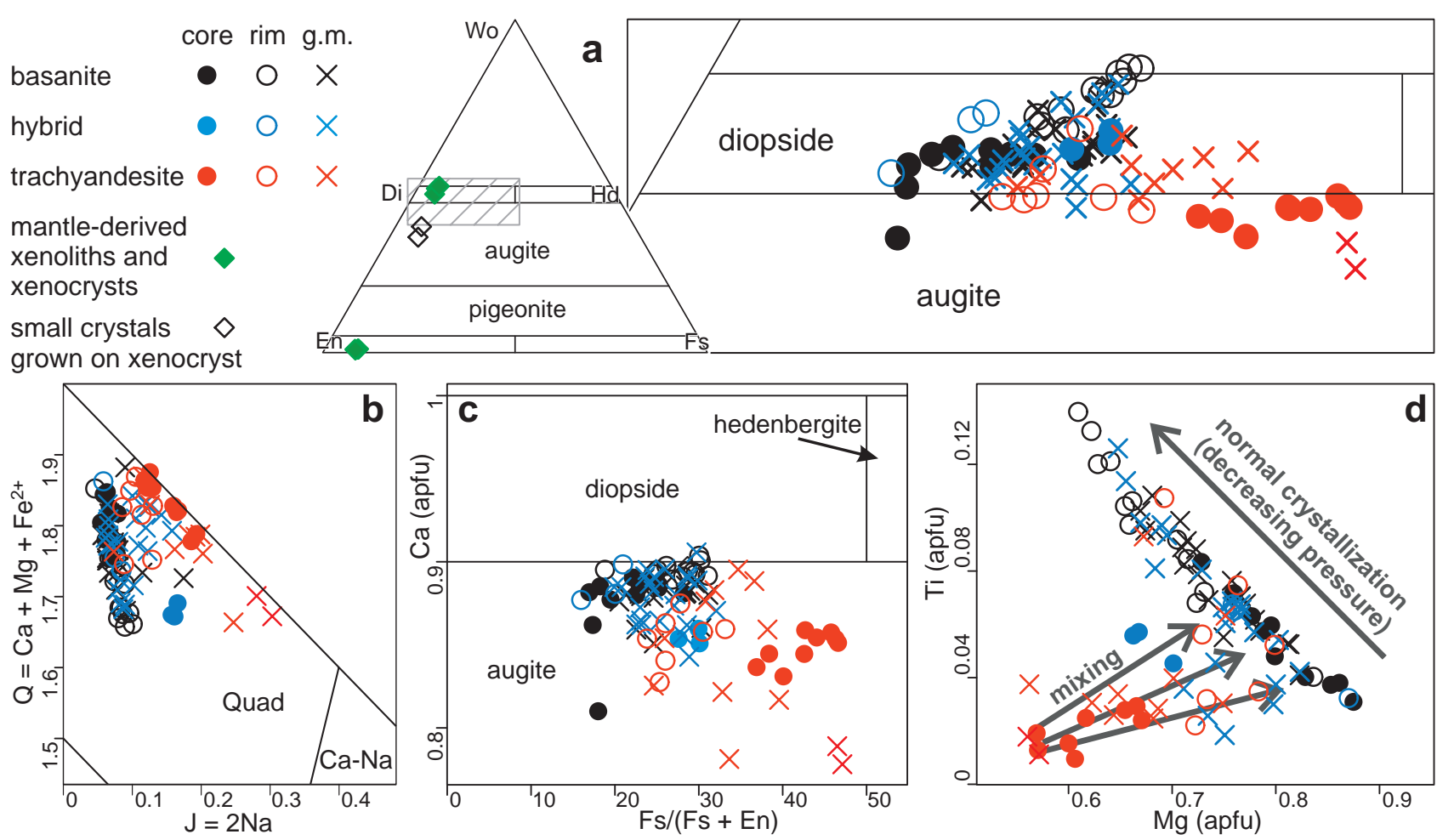

Fig. 7 Clinopyroxene compositions (g.m. - small crystals in groundmass): a - Quadrilateral diagram En-Wo-Fs (Morimoto 1988): Di - diopside, En - enstatite, Fs - ferrosilite, Hd - hedenbergite, Wo - wollastonite; b - J-Q diagram (Morimoto 1988); c - Fs/(Fs + En) vs. Ca (apfu) diagram (Rapprich 2005); d - Binary diagram Mg (apfu) vs. Ti (apfu).

nocrysts and smaller groundmass crystals. It is also a dominant mineral phase in the ubiquitous mantle xenoliths (microprobe data from olivines from both, basanite and mantle xenoliths, are presented in Supplementary Tab. 1). The cores of larger phenocrysts are rich in $\mathrm{Mg}$ $\left(\mathrm{Fo}_{84-92}\right)$, suggesting that some of these cores might represent xenocrystic mantle olivine $\left(\mathrm{Fo}_{>90}\right)$. Occasionally, the olivine cores enclose inclusions of nickel sulfides ( $\mathrm{NiS}$ and $[\mathrm{NiFe}] \mathrm{S})$. The outer rims show significantly lower $\mathrm{MgO}$ contents $\left(\mathrm{Fo}_{70-77.5}\right)$ and the most evolved (Mg-poor) compositions $\left(\mathrm{Fo}_{69-70}\right)$ were observed in small groundmass crystals.

\subsubsection{Clinopyroxene}

Clinopyroxene is present in all rock types documented on Zebín Hill. As it crystallizes under a wide range of conditions, this mineral provides an optimal record of evolution of alkaline melts (e.g., Rapprich 2005; Ronick and Renno 2010; Jankovics et al. 2015). The studied clinopyroxenes occur as both larger phenocrysts and smaller groundmass crystals in pure basanite rocks as well as in all rock-types observed in the mingled hybrid rocks (see Supplementary Tab. 2). The basanites also contain mantle-derived xenoliths with clino- and orthopyroxene with high $\mathrm{MgO}$ contents. The orthopyroxene xenocrysts are coated with small crystals of Ca-poor augite.
In the Fig. 7, symbols for individual analyses reflect the petrology and position of each analysis within the crystals. Most of the analyzed clinopyroxenes fit into the field of diopside on a quadrilateral composition diagram (Morimoto 1988; Fig. 7a), but their relatively low Ca contents (mostly under 0.9 apfu - atoms per formula unit) suggested that these better classify as augites (Fig. 7c; Rapprich 2005).

The Cpx from basanite displays normal zoning, with $\mathrm{Mg}$-rich cores and more Fe-rich rims and small crystals in groundmass. On the other hand, the Cpx phenocrysts in trachyandesite and hybrid domains show reverse zoning. Negative correlation in the Mg-Ti (apfu) plot (Fig. 7d) is a normal crystallization trend reflecting increasing role for $\mathrm{Ca}-\mathrm{Ti}-\mathrm{Tschermak}$ 's substitution $\left(\mathrm{CaTiAl}_{2} \mathrm{O}_{6}\right.$ instead of $\left.\mathrm{CaMgSi}_{2} \mathrm{O}_{6}\right)$ during closed-system, decompression crystallization. This substitution results in Ti-rich rims and groundmass microcrysts compared to Mg-rich cores (e.g., Tracy and Robinson 1977; Rapprich 2005; Haloda et al. 2010). The clinopyroxenes from trachytic rocks are generally poorer in both $\mathrm{Mg}$ and $\mathrm{Ti}$ (e.g., Scott 1976; Carbonin et al. 1984; Rapprich 2005), which corresponds well to the observed composition of clinopyroxene cores in the trachyandesite domains in the mingled dikes from Zebín (Fig. 7d). The rims of the same phenocrysts and the smaller groundmass crystals approach the composition of $\mathrm{Cpx}$ from basaltic rocks. The 

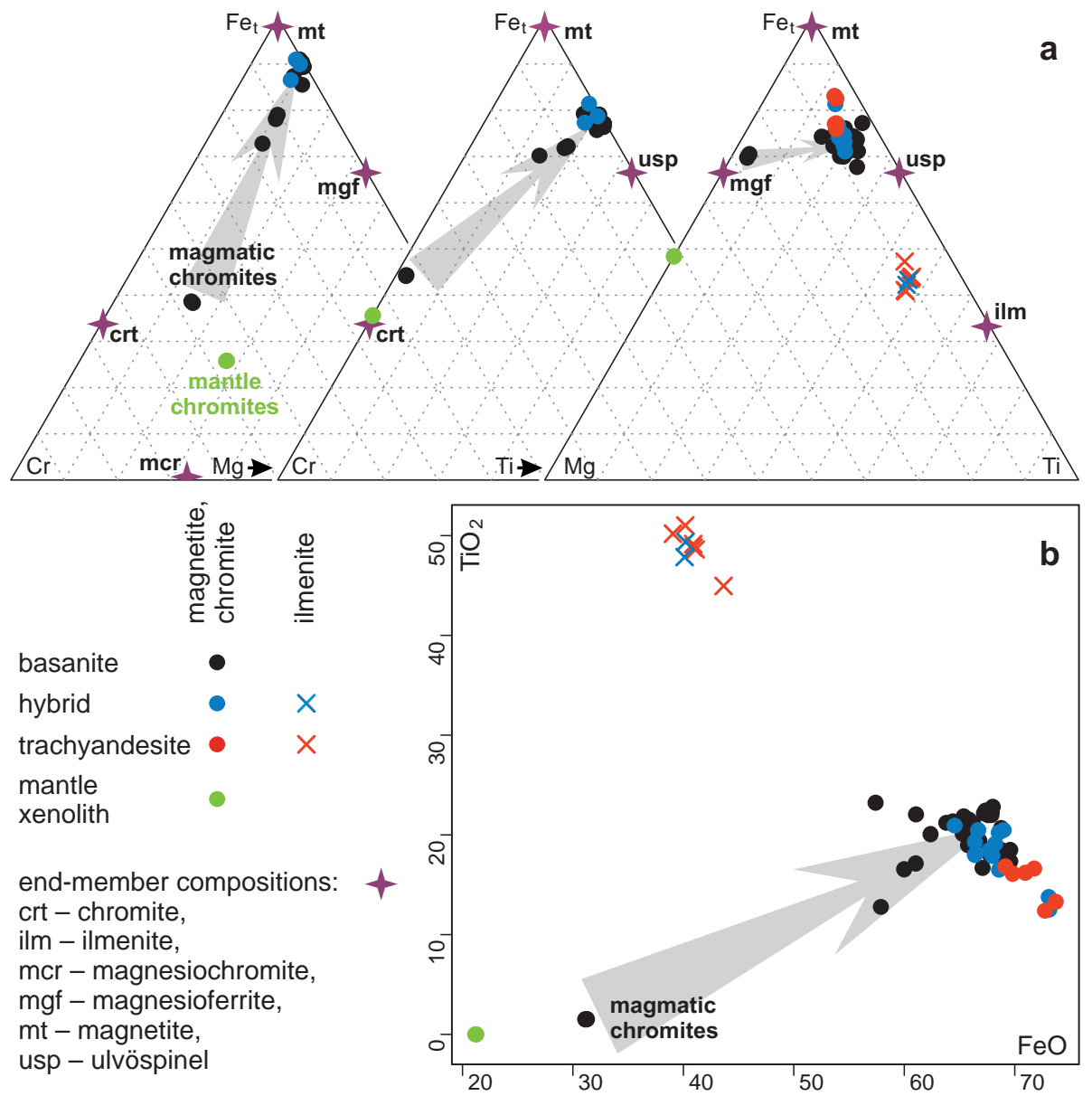

Fig. 8 Composition diagrams for $\mathrm{Fe}-\mathrm{Ti}$ oxides: a $-\mathrm{Cr}-\mathrm{Fe}$ - $\mathrm{Mg}$ (apfu), $\mathrm{Cr}-\mathrm{Fe}_{\mathrm{t}}-$ $\mathrm{Ti}$ (apfu) and $\mathrm{Mg}-\mathrm{Fe}$ - $\mathrm{Ti}$ (apfu) ternary plots showing in addition compositions of spinel group end-members; $\mathbf{b}-\mathrm{Bi}$ nary $\mathrm{FeO}$ vs. $\mathrm{TiO}_{2}$ (wt. \%) diagram with analysed spinel-group minerals and ilmenites. The grey arrows indicate trend from cores of larger crystals towards their rims and groundmass.

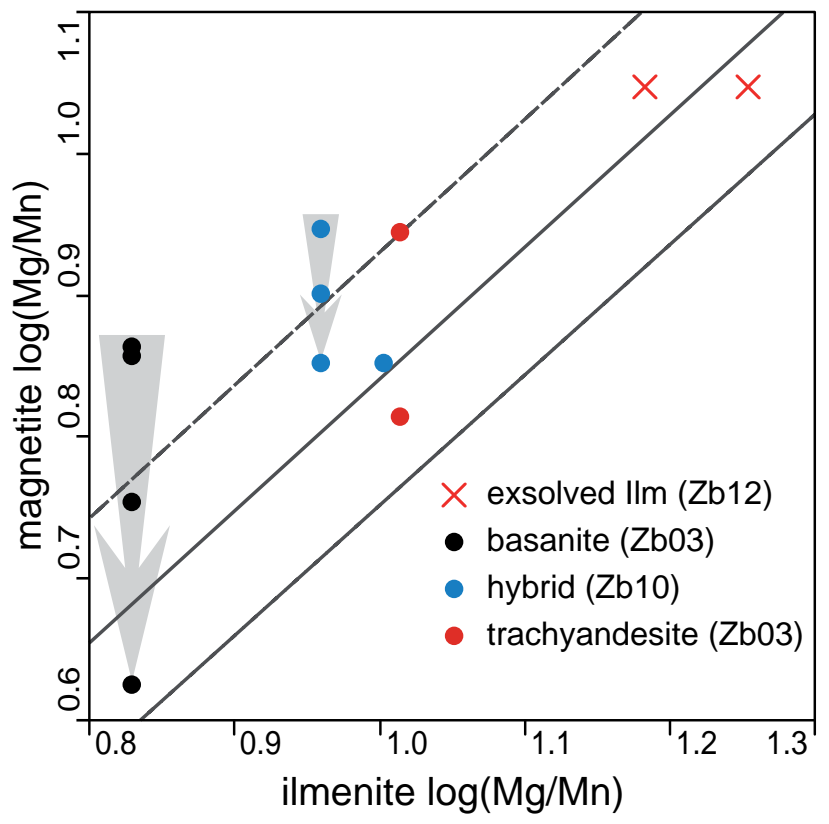

Fig. 9 Test of equilibrium between coexisting Fe-Ti oxides (Bacon and Hirschmann 1988). The grey arrows indicate trend from cores of larger magnetite crystals towards their rims. composition of $\mathrm{Cpx}$ from hybrid rocks plotts on mixing lines and follows the normal basaltic trend.

\subsubsection{Fe-Ti oxides}

$\mathrm{Fe}-\mathrm{Ti}$ oxides are represented by Ti-magnetite and chromite in basanite, and Ti-magnetite and ilmenite in trachyandesite and hybrid rocks (Supplementary Tab. 3). The cores of larger spinelide crystals have chromite composition with Mg-admixture and very low Ti contents (Fig. 8a). The chromites in the cores of idiomorphic crystals differ from Fe-poor mantle-derived chromitemagnesiochromite found in the peridotite xenolith. The composition of spinel-group oxides in basanites follows a trend of decreasing $\mathrm{Cr}$ and $\mathrm{Mg}$ and increasing $\mathrm{Ti}$ and namely $\mathrm{Fe}$ from cores towards rims of larger crystals and groundmass microcrysts (Fig. 8a). Later magnetites from basanite are typical Ti-magnetites close to ulvöspinel. Similar compositions were observed in the hybrid rocks, whereas the trachyandesites contain Ti-low magnetite associated with ilmenite (Fig. 8b).

In several domains, coexisting magnetite and ilmenite grains were documented providing a possibility for equilibrium test according to Bacon and Hirschmann 
(1988; Fig. 9). Coexisting Fe-Ti oxides occur in basanite and trachyandesite domains in the Zb03 mingled dike and hybrid domains in the $\mathrm{Zb} 10$ mingled dike. In addition, magnetite and ilmenite lamellae from the exsolved larger ilmenite crystal in the $\mathrm{Zb} 12$ mingled dike are also plotted. Despite the magnetite cores from basanite, enriched in $\mathrm{Mg}$ and $\mathrm{Cr}$, plot out of the equilibria belt, their rims appear to be in equilibrium with the groundmass ilmenite. Also $\mathrm{Fe}-\mathrm{Ti}$ oxides in trachyandesite domains are equilibrated, as well as groundmass of the hybrid domains, where disequilibrium can be expected among larger phenocrysts or between phenocrysts and groundmass.

\subsubsection{Feldspars and feldspathoids}

Feldspars also reflect a wide compositional range of rocks observed within the dikes of Zebín Volcano (Supplementary Tab. 4). Coherent pure basanites contain plagioclase of labradorite composition (Fig. 10). The labradorite in the basanite is associated with K-nepheline containing 0.1-0.14 K (apfu; Supplementary Tab. 4). The composition of plagioclase in the basanite droplets within the mingled dikes is more sodic (andesine). Most of the feldspars in the trachyandesite veinlets are sanidines, but some anorthoclase and oligoclase crystals are also present. An even wider range of feldspar compositions has been documented from the hybrid domains, including a continuous compositional trend from sanidine to andesine. Neither trachyandesite, nor hybrid domains contain any nepheline. Analcite present in basanite and hybrid domains contains variable admixtures of $\mathrm{Ca}$ (up to $0.11 \mathrm{apfu}$ ), and $\mathrm{Fe}$ (0.025 apfu; Supplementary Tab. 4).

\section{Discussion}

The predominance of basanite compositions in the conduit, dikes, and droplets in the mingled dikes suggests that the Zebín Volcano originated from eruption of primitive mantle-derived magma. The relationships of the composition and liquidus temperatures of olivine and basaltic melts are derived from well-established experimental results and phase equilibrium analyses (e.g., Roeder and Emslie 1970; Bender et al. 1978; Walker et al. 1979; Langmuir and Hanson 1981; Nielsen and Dungan 1983; Weaver and Langmuir 1990; Kinzler and Grove 1992). Based on the defined phase equilibria between olivine and melt, the cores of olivines from the main plug and non-mingled dike $\left(\mathrm{Fo}_{84-92}\right)$ correspond to primitive magma with $\mathrm{Mg} \#$ (molar $\left.\mathrm{MgO} /\left(\mathrm{MgO}+\mathrm{FeO}_{\text {tot }}\right)\right)$ values in the range $0.62-0.74$. These values are in good agreement with bulk-rock analysis of the main plug (CR009), with $\mathrm{Mg} \#=0.66$.

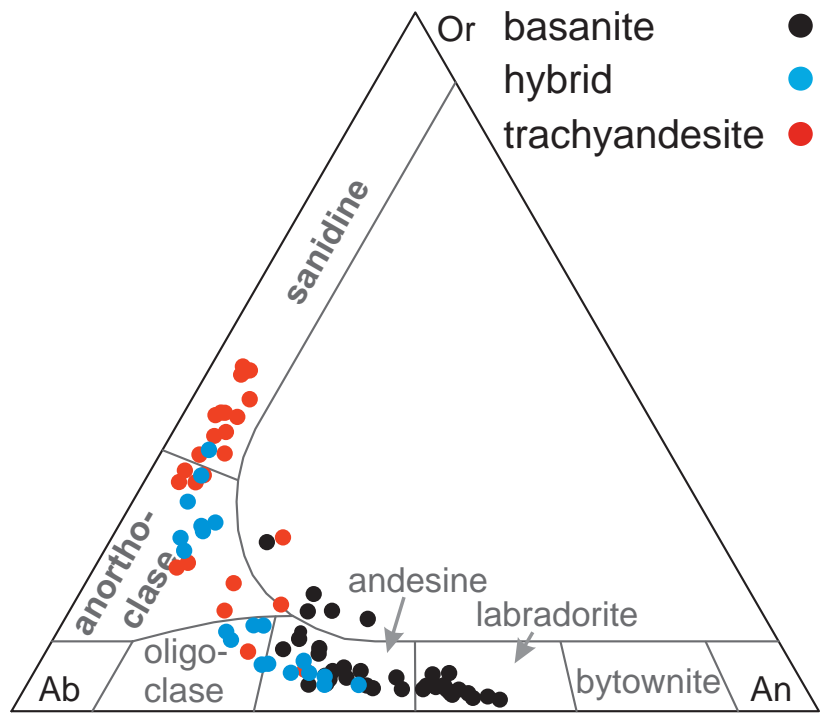

Fig. 10 Classification diagram of analysed feldspars (mol. \%).

The same equilibrium equations can be applied on estimation of olivine crystallization temperatures. The most-magnesian cores correspond to crystallization at around $1260^{\circ} \mathrm{C}$, the outermost rims of the crystals (Mg-poor) at $1130^{\circ} \mathrm{C}$, and fine microcrysts in the groundmass at $1130^{\circ} \mathrm{C}$.

The trachyandesitic veinlets in the mingled dikes could be interpreted as unrelated anatectic magma or as a differentiate of the parental basanite magma. However, it is unlikely that the Zebín system included discrete additions of silicic magmas, as there are no known trachytic or phonolitic bodies within the entire Jičín Volcanic Field (Rapprich et al. 2007). Hence, our preferred interpretation is that the trachyandesite magma is a differentiate of the parental basanite melt. Derivation of trachyandesitic, trachytic and phonolitic magmas from parental basanitic melts through fractionation and assimilation was described by Ackerman et al. (2015) from the neighboring České Středohoří Volcanic Complex. In addition, interstitial glass in the basanite domains in most cases approaches trachyandesitic composition, supporting the idea that the trachyandesite melt represents residual melt after fractionation of basanite magma.

The basanite dikes and basanite domains in mingled dikes show normal mineral zonation trends in olivine, clinopyroxene, and plagioclase indicative of common crystallization with mineral composition reflecting the evolving chemistry of crystallizing magma in a nearlyclosed system (e.g., Tracy and Robinson 1977).

The trachyandesite domains in mingled dikes contain alkali feldspar, low Mg- and Ti-clinopyroxene with reverse zoning (more magnesian rims), and a range of plagioclase feldspar compositions suggestive of magma mixing. The reverse zoning of clinopyroxene suggests that the partly crystallized trachyandesitic magma was 


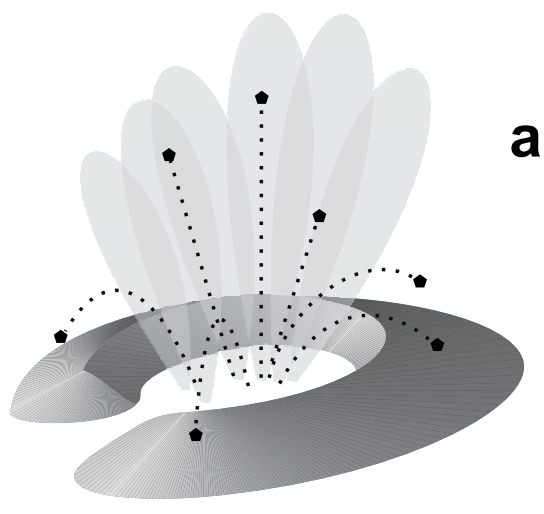

a

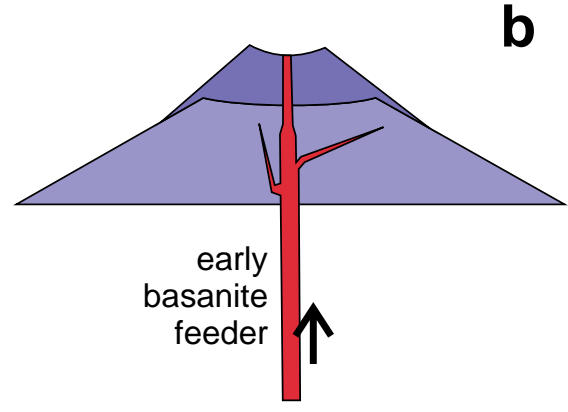

C
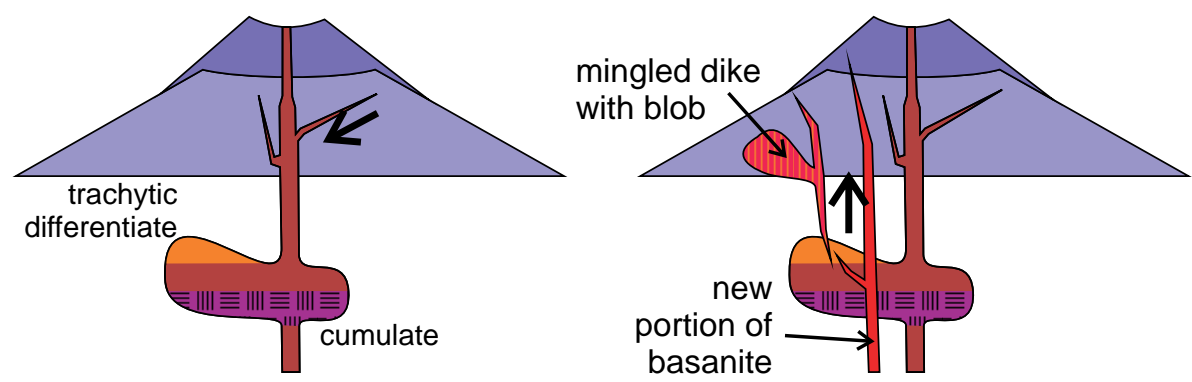

Fig. 11 Volcano evolution model depicting the hypothesized magma plumbing system and magma flow beneath the Zebín Volcano. a Surtseyan style eruption producing a tuff cone; $\mathbf{b}$ - Intrusion of the early basanitic feeder; c - Formation of a temporary magma-reservoir, where magma fractionates; d - Injection of a new portion of primitive basanitic magma. At the last stage, some branches penetrate the pyroclastic deposits, part of the magma intrudes the zoned reservoir, where it mingles with trachyandesitic melt and ascends in the form of mingled dikes. invaded by a new batch of basanitic melt, resulting in mineral compositions becoming more magnesium-rich (e.g., Nakagawa et al. 2002). The basic composition of the glass in the basanite domain within the mingled dike of the sample Zb12 (Tab. 2) may suggest that fresh basanite melt was chilled in the contact with cooler trachyandesitic magma resting in the zoned chamber.

The data overall imply that a zoned magma chamber had to evolve temporarily underneath the Zebín Volcano during the eruption, which was of Surtseyan style (Fig. 11a). The uniform basic composition of pyroclastic deposits documents that the differentiated magma was not available for mingling in the early phase of magmatic activity. Early basanite dikes reached the near-surface without interaction with other magma batches and probably started to infill a temporary magma reservoir (Fig. 11b), where fractionation of basanite to trachyandesite took place (Fig. 11c). Later additions of primary basanite intruded the zoned crystal-melt system, and mingled and mixed with the trachyandesite to produce the mafic droplets and intermediate domains of the mingled dikes (Fig. 11d). Wide spectra of clinopyroxene and feldspar compositions, as well as reverse zoning of clinopyroxene suggest that the intermediate domains originated through the hybridization. Still Fe-Ti oxides in the groundmass imply that the melt became equilibrated at the final stage. The basic input, having a higher solidus temperature than the trachyandesite differentiates, remobilized the system and induced eruption of the mingled dikes. Such reactivation of silicic magma by intrusion of basaltic melt was observed also during recent volcanic eruptions including Ilopango Tierra Blanca Jóven (TBJ; Richer et al. 2004), Pinatubo 1991 (Pallister et al. 1992), and Eyjafjallajökull 2010 (Sigmundsson et al. 2010; Sigmarsson et al. 2011). On the other hand, mingling of compositionally highly contrasting magmas underneath monogenetic volcanoes is rather scarce (Schreiber et al. 1999), especially during the course of the eruption.

\section{Conclusions}

- Petrological data suggest that Zebín Volcano evolved from a parental basanitic magma that differentiated to more silicic compositions, including trachyandesite. The system was repeatedly injected by fresh basanite magma, which mingled and mixed with trachyandesite differentiates to produce hybrid melt domains with a wide range of phenocryst compositions (namely clinopyroxenes and feldspars).

- Complex magma feeding/storage systems with magmatic processes including fractional crystallization or mingling/mixing may develop also underneath small monogenetic volcanoes at scales of hundreds of meters.

Acknowledgements. Petrological research on Zebín Hill was supported by the Czech Science Foundation (GACR) project P210/12/1990 (to Rapprich and Halodová). We are also indebted to National Geographic Society (grant \#8887-11) and National Science Foundation (grant 
1423396) for supporting Shields, Petronis and Lindline. Special thanks go to Dr. Tomáš Řídkošil, former director of the Český Ráj Geopark, for help with organizing the field campaign and to the Landscape Protection Authority of the Hradec Králové regional government for permission to collect samples. Dr. Tomáš Řídkošil passed away on July $2^{\text {nd }} 2015$ at the age of 62 . We dedicate this manuscript to his memory. We are grateful to Christoph Breitkreuz and an anonymous reviewer as well as to handling editor John Hora for constructive comments, which pulled the quality of the manuscript significantly forward.

Electronic supplementary material. Supplementary tables of chemical compositions with recalculated crystalformulae of olivines, pyroxenes, Fe-Ti oxides, feldspars and feldspathoids are available online at the Journal web site (http://dx.doi.org/10.3190/jgeosci.245).

\section{References}

Ackerman L, Ulrych J, Řanda Z, Erban V, Hegner E, Magna T, Balogh K, Frána J, Lang M, Novák JK (2015) Geochemical characteristics and petrogenesis of phonolites and trachytic rocks from the České Středohoří Volcanic Complex, the Ohře Rift, Bohemian Massif. Lithos 224: 256-271

AWDANKIEWICZ M (2005) Reconstructing an eroded scoria cone: the Miocene Sośnica Hill Volcano (Lower Silesia, SW Poland). Geol Q 49: 439-448

Awdankiewicz M, Rapprich V, Míková J (2016) Magmatic evolution of compositionally heterogeneous monogenetic Cenozoic Strzelin Volcanic Field (Fore-Sudetic Block, SW Poland). J Geosci 61: 425-450

BACON CR, Hirschmann MM (1988) Mg/Mn partitioning as a test for equilibrium between coexisting Fe-Ti oxides. Amer Miner 73: 57-61

Bender JF, Hodges FN, Bence AE (1978) Petrogenesis of basalts from the project Famous area: experimental study from 0 to 15 kbars. Earth Planet Sci Lett 41: 277-302

Blaikie TN, Ailleres L, Betts PG, Cas RAF (2014) A geophysical comparison of the diatremes of simple and complex maar volcanoes, Newer Volcanics Province, south-eastern Australia. J Volcanol Geotherm Res 276: 64-81

Brenna M, Cronin SJ, Smith IE, Sohn YK, Németh K (2010) Mechanisms driving polymagmatic activity at a monogenetic volcano, Udo, Jeju Island, South Korea. Contrib Mineral Petrol 160: 931-950

BüCHner J, Tietz O (2012) Reconstruction of the Landeskrone Scoria Cone in the Lusatian Volcanic Field, Eastern Germany - long-term degradation of volcanic edifices and implications for landscape evolution. Geomorphology 151: 175-187
Büchner J, Tietz O, Viereck L, Suhr P, Abratis M (2015) Volcanology, geochemistry and age of the Lausitz Volcanic Field. Int J Earth Sci (Geol Rundsch) 104: 2057-2083

CAJZ V, RAPPRICH V, ERBAN V, PÉCSKAY Z, RADOŇ M (2009) Late Miocene volcanic activity in the České Středohoří Mountains (Ohře/Eger Graben, northern Bohemia). Geol Carpath 60: 519-533

Carbonin S, Dal Negro A, Molin GM, Munno R, Rossi G, Lirer L, Piccirillo EM (1984) Crystal chemistry of Ca-rich pyroxenes from undersaturated to oversaturated trachytic rocks, and their relationships with pyroxenes from basalts. Lithos 17: 191-202

Coubal M, Adamovič J, Málek J, Prouza V (2014) Architecture of thrust faults with along strike variations in fault-plane dip: anatomy of the Lusatian Fault, Bohemian Massif. J Geosci 59: 183-208

ČECH S (ed) (2013) Basic geological map of the Czech Republic 1:25 000, 03-342 Rovensko pod Troskami with Explanation. Czech Geological Survey, Prague (in Czech)

Delacour A, Gerbe MC, Thouret JC, Wörner G, PaQUEREAU-LEBTI P (2007) Magma evolution of Quaternary minor volcanic centres in southern Peru, Central Andes. Bull Volcanol 69: 581-608

DempÍrová L, ŠIKL J, KAŠIČKOVÁ R, ZoulKová V, KříBEK $B$ (2010) The evaluation of precision and relative error of the main components of silicate analyses in Central Laboratory of the Czech Geological Survey. Zpr Geol Výzk v Roce 2009: 326-330 (in Czech)

DÈzES P, SCHMID SM, ZIEGLER PA (2004) Evolution of the European Cenozoic Rift System: interaction of the Alpine and Pyrenean orogens with their foreland lithosphere. Tectonophysics 389: 1-33

Di Roberto A, Bertagnini A, Pompilio M, Bisson M (2014) Pyroclastic density currents at Stromboli Volcano (Aeolian Islands, Italy): a case study of the 1930 eruption. Bull Volcanol 76: 827

Erlund EJ, Cashman KV, Wallace PJ, Pioli L, Rosi M, Johnson E, Granados HD (2010) Compositional evolution of magma from Parícutin Volcano, Mexico: the tephra record. J Volcanol Geotherm Res 197: 167-187

HaAse KM, Beier C, Regelous M, Rapprich V, Renno A (2017) Spatial variability of source composition and petrogenesis in rift and rift flank alkaline lavas from the Eger Rift, Central Europe. Chem Geol 455: 304-314

Haloda J, Rapprich V, Holub FV, Halodová P, VACULOVIČ T (2010) Crystallization history of Oligocene ijolitic rocks from the Doupovské hory Volcanic Complex (Czech Republic). J Geosci 55: 279-297

Hamelin C, Seitz H-M, Barrat J-A, Dosso L, Maury RC, Chaussidon M (2009) A low $\delta^{7}$ Li lower crustal component: evidence from an alkalic intraplate volcanic series (Chaîne des Puys, French Massif Central). Chem Geol 266: 214-226 
Holub FV, Rapprich V, Erban V, PÉcskay Z, MLČoch B, Míková J (2010) Petrology and geochemistry of the Tertiary alkaline intrusive rocks at Doupov, Doupovské hory Volcanic Complex (NW Bohemian Massif). J Geosci 55: 251-278

Jankovics MÉ, Harangi S, Németh K, Kiss B, Ntaflos $\mathrm{T}$ (2015) A complex magmatic system beneath the Kissomlyó monogenetic volcano (western Pannonian Basin): evidence from mineral textures, zoning and chemistry. J Volcanol Geotherm Res 301: 38-55

JANOUŠEK V, FARROW CM, ERBAN V (2006) Interpretation of whole-rock geochemical data in igneous geochemistry: introducing Geochemical Data Toolkit (GCDkit). J Petrol 47: 1255-1259

Kinzler RJ, Grove TL (1992) Primary magmas of midocean ridge basalts 1. Experiments and methods. J Geophys Res: Solid Earth 97(B5): 6885-6906

Klügel A, Hoernle KA, Schmincke H-U, White JD (2000) The chemically zoned 1949 eruption on La Palma (Canary Islands): petrologic evolution and magma supply dynamics of a rift zone eruption. J Geophys Res: Solid Earth 105(B3): 5997-6016

LANGMUIR CH, HANSON GN (1981) Calculating mineralmelt equilibria with stoichiometry, mass balance, and single component distribution coefficients. In: NEWTON RC, Navrotsky A, Wood BJ (eds) Thermodynamics of Minerals and Melts. Advances in Physical Geochemistry Vol 1, Springer Verlag, New York, pp 247-271

LoRENZ V, KurSZLAUKIS S (2007) Root zone processes in the phreatomagmatic pipe emplacement model and consequences for the evolution of maar-diatreme volcanoes. J Volcanol Geotherm Res 159: 4-32

Morimoto N (1988) Nomenclature of pyroxenes. Mineral Petrol 39: 55-76

NAKAGaWA M, WAda K, Wood CP (2002) Mixed magmas, mush chambers and eruption triggers: evidence from zoned clinopyroxene phenocrysts in andesitic scoria from the 1995 eruptions of Ruapehu volcano, New Zealand. J Petrol 43: 2279-2303

NÉMETH K (2010) Monogenetic volcanic fields: origin, sedimentary record, and relationship with polygenetic volcanism. In: CAÑóN-TAPIA E, SzAKÁCs A (eds) What is a Volcano? Geological Society of America Special Papers 470: 43-66

Németh K, White JDL, Reay A, Martin U (2003) Compositional variation during monogenetic volcano growth and its implications for magma supply to continental volcanic fields. J Geol Soc, London 160: 523-530

Nielsen RL, Dungan MA (1983) Low pressure mineralmelt equilibria in natural anhydrous mafic systems. Contrib Mineral Petrol 84: 310-326

Orozco-Esquivel T, Petrone CM, Ferrari L, Tagami T, MANETti P (2007) Geochemical and isotopic variability in lavas from the eastern Trans-Mexican Volcanic Belt: slab detachment in a subduction zone with varying dip. Lithos 93: 149-174

Pallister JS, Hoblitt RP, Reyes AG (1992) A basalt trigger for the 1991 eruptions of Pinatubo Volcano? Nature 356: 426-428

Pérez-López R, Legrand D, Garduño-Monroy VH, Rodríguez-Pascua MA, Giner-Robles JL (2011) Scaling laws of the size-distribution of monogenetic volcanoes within the Michoacán-Guanajuato Volcanic Field (Mexico). J Volcanol Geotherm Res 201: 65-72

Petronis MS, Delcamp A, van WyK de Vries B (2013) Magma emplacement into the Lemptégy scoria cone (Chaîne Des Puys, France) explored with anisotropy of magnetic susceptibility, and paleomagnetic data. Bull Volcanol 75: 753

Petronis MS, Brister A, RAPprich V, van Wyk de VRies B, Lindline J, MišUREC J (2015) Emplacement history of the Trosky basanitic volcano (Czech Republic): paleomagnetic, rock magnetic, petrologic, and anisotropy of magnetic susceptibility evidence for lingering growth of a monogenetic volcano. J Geosci 60: 129-147

RaJCHL M, UličnÝ D, GRYGaR R, MACH K (2008) Evolution of basin architecture in an incipient continental rift: the Cenozoic Most Basin, Eger Graben (Central Europe). Basin Res 21: 269-294

RAPPRICH V (2005) Compositional variation of clinopyroxenes of basaltic, essexitic and tephriphonolitic rocks from the Doupovské hory Volcanic Complex, NW Bohemia. J Geosci 50: 119-132

RAPPRICH V, HoLUB FV (2008) Geochemical variations within the Upper Oligocene-Lower Miocene lava succession of Úhošt' Hill (NE margin of Doupovské hory Mts., Czech Republic). Geol Q 52: 253-268

RAPPRICH V, CAJZ V, KošŤÁK M, PÉCSKAY Z, ŘíDKoŠIL T, RAŠKA P, RADOŇ M (2007) Reconstruction of eroded monogenic Strombolian cones of Miocene age: a case study on character of volcanic activity of the Jičín Volcanic Field (NE Bohemia) and subsequent erosional rates estimation. J Geosci 52: 169-180

Richer M, Mann CP, Stix J (2004) Mafic magma injection triggers eruption at Ilopango caldera, El Salvador, Central America. In: Rose WI, Bommer JJ, López DL, CARr MJ, Major JJ (eds) Natural Hazards in El Salvador. Geological Society of America Special Papers 375: $175-190$

RoEDER PL, EMSLIE R (1970) Olivine-liquid equilibrium. Contrib Mineral Petrol 29: 275-289

Ronick R, RENNo AD (2010) Clinopyroxene from basaltic rocks of the Erzgebirge-Krušné hory Mts. - implications for modelling the magmatic plumbing system. J Geosci 55: 231-249

Rosi M, Bertagnini A, Harris AJl, Pioli L, Pistolesi M, RIPEPE M (2006) A case history of paroxysmal explosion 
at Stromboli: timing and dynamics of the April 5, 2003 event. Earth Planet Sci Lett 243: 594-606

Schmincke H-U (1977) Phreatomagmatische Phasen in quartären Vulkanen der Osteifel. Geol Jahrb 39: 3-45

Schreiber U, Anders D, Koppen J (1999) Mixing and chemical interdiffusion of trachytic and latitic magma in a subvolcanic complex of the Tertiary Westerwald (Germany). Lithos 46: 695-714

ScotT PW (1976) Crystallization trends of pyroxenes from the alkaline volcanic rocks of Tenerife, Canary Islands. Mineral Mag 40: 805-816

Shields S, Petronis MS, Rapprich V, Lindline J, Valenta J, FALANCE JJ (2016) A multi-disciplinary study evaluating magma emplacement processes of the Oligocene Zákupy diatreme (Czech Republic). AGU Fall Meeting Abstracts: V53C-3130

Sigmarsson O, Vlastelic I, Andreasen R, Bindeman I, Devidal JL, Moune S, Keiding JK, Larsen G, HöSKULDSSON A, THORDARSON T (2011) Remobilization of silicic intrusion by mafic magmas during the 2010 Eyjafjallajökull eruption. Solid Earth 2: 271-281

Sigmundsson F, HreinsdótTir S, Hooper A, Árnadóttir T, Pedersen R, Roberts MJ, Óskarsson N, Auriac A, Decriem J, Einarsson P, Geirsson H, Hensch M, Ófeigsson BG, Sturkell E, Sveinbjörnsson H, Feigl KL (2010) Intrusion triggering of the 2010 Eyjafjallajökull explosive eruption. Nature 468: 426-430

Skála R, Ulrych J, Ackerman L, Jelínek E, Dostál J, Hegner E, RAndA Z (2014) Tertiary alkaline Roztoky Intrusive Complex, České Středohoří Mts., Czech Republic: petrogenetic characteristics. Int J Earth Sci (Geol Rundsch) 103:1233-1262

TiETZ O, BüCHNER J (2015) The landscape evolution of the Lausitz Block since the Palaeozoic - with special emphasis to the neovolcanic edifices in the Lausitz Volcanic Field (Eastern Germany). Z Dtsch Ges Geowiss 166: 125-147

Tracy RJ, Robinson P (1977) Zoned titanian augite in alkali olivine basalt from Tahiti and the nature of titanium substitution in augite. Amer Miner 62: 634-645
ULIČNÝ D (2001) Depositional systems and sequence stratigraphy of coarse-grained deltas in a shallow-marine, strike-slip setting: the Bohemian Cretaceous Basin, Czech Republic. Sedimentology 48: 599-628

UličnÝ D, LAurin J, ČECH S (2009) Controls on clastic sequence geometries in a shallow-marine, transtensional basin: the Bohemian Cretaceous Basin, Czech Republic. Sedimentology 56: 1077-1114

Ulrych J, Svobodová J, Balogh K (2002) The source of Cenozoic volcanism in the České Středohoří Mts., Bohemian Massif. Neu Jb Mineral, Abh 177: 133-162

Ulrych J, Dostal J, Adamovič J, Jelínek E, ŠpačEK P, Hegner E, Balogh K (2011) Recurrent Cenozoic volcanic activity in the Bohemian Massif (Czech Republic). Lithos 123: 133-144

Ulrych J, KrmíčEK L, TOMEK Č, Lloyd FE, LADENBERGER A, Ackerman L, Balogh K (2016) Petrogenesis of Miocene alkaline volcanic suites from western Bohemia: whole rock geochemistry and $\mathrm{Sr}-\mathrm{Nd}-\mathrm{Pb}$ isotopic signatures. Chem Erde 76: 77-93

Valenta J, Rapprich V, Skácelová Z, Gaždová R, FoJTíkoví L (2014) The newly discovered Neogene maar volcano near the Mariánské Lázně, Western Bohemia. Acta Geodyn Geomater 11: 107-116

VANĚČKovÁ M, Holub FV, SOUČEK J, Bowes DR (1993) Geochemistry and petrogenesis of the Tertiary alkaline volcanic suite of the Labe Tectono-Volcanic Zone, Czech Republic. Mineral Petrol 48: 17-34

Vieten K, HAmm HM (1978) Additional notes On the calculation of the crystal chemical formula of clinopyroxenes and their contents of $\mathrm{Fe}^{3+}$ from microprobe analyses. Neu Jb Mineral, Mh 2: 71-83

Walker D, Shibata T, DeLong SE (1979) Abyssal tholeiites from the Oceanographer fracture zone. Contrib Mineral Petrol 70: 111-125

Weaver JS, Langmuir CH (1990) Calculation of phase equilibrium in mineral-melt systems. Comput and Geosci 16: 1-19 